\title{
The use of lactoperoxidase for the bleaching of fluid whey
}

\author{
R. E. Campbell, ${ }^{*}$ E. J. Kang, ${ }^{*}$ E. Bastian, $\dagger$ and M. A. Drake ${ }^{\star 1}$ \\ *Department of Food, Bioprocessing and Nutrition Sciences, Southeast Dairy Foods Research Center, North Carolina State University, \\ Raleigh 27695 \\ †Glanbia Nutritionals, Twin Falls, ID 83301
}

\begin{abstract}
Lactoperoxidase (LP) is the second most abundant enzyme in bovine milk and has been used in conjunction with hydrogen peroxide $\left(\mathrm{H}_{2} \mathrm{O}_{2}\right)$ and thiocyanate $\left(\mathrm{SCN}^{-}\right)$to work as an antimicrobial in raw milk where pasteurization is not feasible. Thiocyanate is naturally present and the lactoperoxidase system purportedly can be used to bleach dairy products, such as whey, with the addition of very little $\mathrm{H}_{2} \mathrm{O}_{2}$ to the system. This study had 3 objectives: 1) to quantify the amount of $\mathrm{H}_{2} \mathrm{O}_{2}$ necessary for bleaching of fluid whey using the LP system, 2) to monitor LP activity from raw milk through manufacture of liquid whey, and 3) to compare the flavor of whey protein concentrate $80 \%$ (WPC80) bleached by the LP system to that bleached by traditional $\mathrm{H}_{2} \mathrm{O}_{2}$ bleaching. Cheddar cheese whey with annatto $(15 \mathrm{~mL}$ of annatto $/ 454 \mathrm{~kg}$ of milk, annatto with $3 \% \mathrm{wt} / \mathrm{vol}$ norbixin content) was manufactured using a standard Cheddar cheesemaking procedure. Various levels of $\mathrm{H}_{2} \mathrm{O}_{2}(5-100 \mathrm{mg} / \mathrm{kg})$ were added to fluid whey to determine the optimum concentration of $\mathrm{H}_{2} \mathrm{O}_{2}$ for LP activity, which was measured using an established colorimetric method. In subsequent experiments, fat-separated whey was bleached for $1 \mathrm{~h}$ with $250 \mathrm{mg}$ of $\mathrm{H}_{2} \mathrm{O}_{2} / \mathrm{kg}$ (traditional) or $20 \mathrm{mg}$ of $\mathrm{H}_{2} \mathrm{O}_{2} /$ $\mathrm{kg}$ (LP system). The WPC80 was manufactured from whey bleached with $250 \mathrm{mg}$ of $\mathrm{H}_{2} \mathrm{O}_{2} / \mathrm{kg}$ or $20 \mathrm{mg}$ of $\mathrm{H}_{2} \mathrm{O}_{2} / \mathrm{kg}$. All samples were subjected to color analysis (Hunter color values and norbixin extraction) and proximate analysis (fat, protein, and moisture). Sensory and instrumental volatile analyses were conducted on WPC80. Optimal LP bleaching in fluid whey occurred with the addition of $20 \mathrm{mg}$ of $\mathrm{H}_{2} \mathrm{O}_{2} / \mathrm{kg}$. Bleaching of fluid whey at either 35 or $50^{\circ} \mathrm{C}$ for $1 \mathrm{~h}$ with LP resulted in $>99 \%$ norbixin destruction compared with 32 or $47 \%$ destruction from bleaching with $250 \mathrm{mg}$ of $\mathrm{H}_{2} \mathrm{O}_{2} /$ $\mathrm{kg}$, at 35 or $50^{\circ} \mathrm{C}$ for $1 \mathrm{~h}$, respectively. Higher aroma intensity and increased lipid oxidation compounds were documented in WPC80 from bleached whey compared
\end{abstract}

Received November 21, 2011.

Accepted February 18, 2012.

${ }^{1}$ Corresponding author: maryanne_drake@ncsu.edu with WPC80 from unbleached whey. Monitoring of LP activity throughout cheese and whey manufacture showed that LP activity sharply decreased after $30 \mathrm{~min}$ of bleaching ( $17.01 \pm 1.4$ to $<1 \mathrm{U} / \mathrm{mL})$, suggesting that sufficient bleaching takes place in a very short amount of time. Lactoperoxidase averaged $13.01 \pm 0.7 \mathrm{U} / \mathrm{mL}$ in unpasteurized, fat-separated liquid whey and 138.6 $\pm 11.9 \mathrm{U} / \mathrm{mL}$ in concentrated retentate (11\% solids). Lactoperoxidase may be a viable alternative for chemical whey bleaching.

Key words: whey, flavor, bleaching, lactoperoxidase

\section{INTRODUCTION}

Lactoperoxidase $(\mathbf{L P})$ is an oxidoreductase enzyme belonging to the peroxidase family and is found in a wide range of mammalian milks, including humans (Seifu et al., 2005). This enzyme is heat stable and is inactivated after $15 \mathrm{~s}$ at $78^{\circ} \mathrm{C}$ (de Wit and van Hooijdonk, 1996). Historically, the LP system has been used to inhibit microbial growth in bovine milk. The LP system consists of 3 components: LP, thiocyanate $\left(\mathrm{SCN}^{-}\right)$, and hydrogen peroxide $\left(\mathrm{H}_{2} \mathrm{O}_{2}\right)$. The system is not active unless all 3 components are present in sufficient amounts (Seifu et al., 2005). The major intermediate oxidation product of the LP-catalyzed oxidation of $\mathrm{SCN}^{-}$is the hypothiocyanate ion $\left(\mathrm{OSCN}^{-}\right)$, which is bactericidal (Seifu et al., 2005). Hydrogen peroxide is sometimes added to activate the system if no $\mathrm{H}_{2} \mathrm{O}_{2}$ is naturally present. Catalase-negative organisms (such as lactic acid bacteria) can generate $\mathrm{H}_{2} \mathrm{O}_{2}$ under aerobic conditions and, thus, can also activate the LP system. Many lactobacilli, lactococci, and streptococci produce sufficient $\mathrm{H}_{2} \mathrm{O}_{2}$ under aerobic conditions to activate the LP system (Seifu et al., 2005). Exogenous $\mathrm{H}_{2} \mathrm{O}_{2}$ must be added to activate the system (Reiter and Harnulv, 1982 ) if it is not supplied by catalase-negative organisms. Gram-negative, catalase-positive organisms (such as Pseudomonas spp., coliforms, salmonellae, and shigellae) are not only inhibited by the LP system, but may be killed, provided that $\mathrm{H}_{2} \mathrm{O}_{2}$ is supplied exogenously (Seifu et al., 2005). Gram-positive, catalasenegative bacteria (such as streptococci and lactococci) are generally inhibited but not killed by the LP system 
(Seifu et al., 2005). If raw milk is stored at $\leq 15^{\circ} \mathrm{C}$, the LP system can effectively preserve raw milk for 24 to 26 h (Reiter and Harnulv, 1982).

Measurement of LP can be done using a variety of methods and, as such, LP activity values vary widely in the literature. In 1994, a method was established to quantify LP activity (Pruitt and Kamau, 1994). This assay uses 2,2'-azino-bis-(3-ethylbenzothiazoline6-sulphonic acid) (ABTS) as a chromophore and the measurement is carried out at $412 \mathrm{~nm}$. This method has been widely accepted (Pruitt and Kamau, 1994). Bovine milk contains 1.2 to $19.4 \mathrm{U}$ of $\mathrm{LP} / \mathrm{mL}$ (Seifu et al., 2005), although levels in liquid whey are reported to be $30 \mathrm{mg} / \mathrm{L}$ or about $0.5 \%$ (wt/wt) of whey proteins (de Wit and van Hooijdonk, 1996). Levels of LP can vary depending on the lactation cycle of the cow, season, feeding regimen, and breed (Kussendrager and van Hooijdonk, 2000). Like LP, thiocyanate can vary widely due to feeding regimen (Seifu et al., 2005). The third component of the LP system, $\mathrm{H}_{2} \mathrm{O}_{2}$, is not normally detected in raw milk and is typically added exogenously. Hydrogen peroxide can be generated endogenously by bacteria, although amounts sufficient to activate the LP system may not be generated (Seifu et al., 2005). Depending on the milk, any 1 of the 3 components that make up the LP system could become the limiting factor.

In addition to inhibiting microbial growth, $\mathrm{OSCN}^{-}$ (produced when LP reacts with $\mathrm{SCN}^{-}$), also has bleaching capabilities. The strong oxidizing capacity allows $\mathrm{OSCN}^{-}$to react with carotenoids, leading to destruction of conjugation and subsequent color loss of norbixin. Very few papers have investigated the use of the LP system for decolorization of whey, and no scholarly journal articles to our knowledge have been published. Bottomley et al. (1989) published a patent describing the decolorizing of whey and products derived from whey using the LP system. Though some process details were provided, quantitative norbixin destruction was not addressed, LP activity was not monitored throughout processing, and the flavor of the finished product was not addressed. Subsequently, all of these items were a focus of the current study. The United States is a major consumer of yellow Cheddar cheese, in which the natural colorant, annatto, comprising the carotenoids bixin and norbixin, is added. Some of the color remains in the liquid whey following curd separation and it is necessary to bleach the whey to achieve a desired lack of color in dried whey ingredients (Kang et al., 2010). The objectives of this study were to quantify the amount of $\mathrm{H}_{2} \mathrm{O}_{2}$ necessary for optimal bleaching using the LP system in fluid whey, to monitor LP activity throughout cheesemaking and whey processing, and to compare the flavor of whey protein concentrate $80 \%$
(WPC80) bleached by the LP system to that bleached by high levels of $\mathrm{H}_{2} \mathrm{O}_{2}$ (traditional chemical bleaching). The overall goal of this study was to determine if whey bleaching via the LP system would be a viable alternative to chemical $\mathrm{H}_{2} \mathrm{O}_{2}$ bleaching for the dairy industry.

\section{MATERIALS AND METHODS}

\section{Experimental Design Overview}

Two experimental components were involved: liquid whey trials and the production of WPC80. Optimum $\mathrm{H}_{2} \mathrm{O}_{2}$ levels to activate the LP system were first determined. Liquid whey trials were then conducted as a 2 by 3 factorial design with temperature $\left(35\right.$ or $\left.50^{\circ} \mathrm{C}\right)$ and bleach treatment [control, $20 \mathrm{mg}$ of $\mathrm{H}_{2} \mathrm{O}_{2} / \mathrm{kg}$ (LP), or $250 \mathrm{mg}$ of $\left.\mathrm{H}_{2} \mathrm{O}_{2} / \mathrm{kg}(\mathbf{H P})\right]$. The samples with the highest bleaching efficacy were then selected for WPC80 manufacture. All samples within each trial were made from the same lot of milk. Lactoperoxidase and $\mathrm{SCN}^{-}$ were monitored throughout the entire process of cheese and whey manufacture. All experiments were conducted in triplicate.

\section{Production of Liquid Whey}

Cheddar whey was manufactured from vat pasteurized whole bovine milk (195 kg) as described by Campbell et al. (2011). Double strength annatto color (3\% norbixin wt/vol; Danisco USA Inc., New Century, KS) was added at $15 \mathrm{~mL} / 454 \mathrm{~kg}$ of milk and diluted 20 times in deionized water before addition to pasteurized milk. The whey was drained from the curds at $\mathrm{pH} 6.35$ and a sieve was used to remove any remaining particles. The whey was immediately processed with a hot bowl cream separator (model SI600E; Agri-Lac Tecnologia Lactea, Miami, FL) to decrease the fat content.

\section{Activation of the LP System}

The optimum level of $\mathrm{H}_{2} \mathrm{O}_{2}$ to activate the LP system was determined by adding $0,5,10,15,20,25,30,35$, $40,45,50,55,60,65,70,75,80,85,90,95$, or 100 $\mathrm{mg}$ of $\mathrm{H}_{2} \mathrm{O}_{2} / \mathrm{kg}$ to unpasteurized, fat-separated liquid Cheddar whey. Bleaching was then carried out as described below. The concentration of $\mathrm{H}_{2} \mathrm{O}_{2}$ that resulted in the most bleaching $[20 \mathrm{mg} / \mathrm{kg}$, according to percent destruction via the degree of yellowness or blueness (b*) reflectance values] was selected for further trials.

\section{LP and HP Bleaching}

Small aliquots $(50 \mathrm{~mL})$ of liquid whey were placed in amber glass jars to prevent light degradation. The 
jars were placed in a water bath at either 35 or $50^{\circ} \mathrm{C}$ and allowed to equilibrate. To activate the LP system, $20 \mathrm{mg}$ of $\mathrm{H}_{2} \mathrm{O}_{2} / \mathrm{kg}$ (35\% wt/vol; Nelson Jameson Inc., Marshfield, WI) was added and allowed to bleach in the water bath at either 35 or $50^{\circ} \mathrm{C}$ for $1 \mathrm{~h}$ with gentle agitation. For HP chemical bleaching, $250 \mathrm{mg}$ of $\mathrm{H}_{2} \mathrm{O}_{2}$ / $\mathrm{kg}$ was added to liquid whey and allowed to bleach for $1 \mathrm{~h}$ with gentle agitation. The latter concentration of $\mathrm{H}_{2} \mathrm{O}_{2}$ was selected because it represents the mid range of the legally allowed amount of $\mathrm{H}_{2} \mathrm{O}_{2}$ for traditional chemical bleaching of whey and also represents a concentration that might be applied by industry (Kang et al., 2010; Listiyani et al., 2011, 2012). Peroxide test strips (EMD Chemicals, VWR International LLC, West Chester, PA) were used to determine if any $\mathrm{H}_{2} \mathrm{O}_{2}$ was leftover after the bleaching treatment. If so, catalase $(20 \mathrm{mg} / \mathrm{kg}$, FoodPro CAT; Danisco USA Inc.) was added at $20 \mathrm{mg} / \mathrm{kg}$ to deactivate $\mathrm{H}_{2} \mathrm{O}_{2}$. The samples were then pasteurized $\left(63^{\circ} \mathrm{C}\right.$ for $\left.30 \mathrm{~min}\right)$ and then immediately cooled on ice. Measurements, including the amount of $\mathrm{LP}$ and $\mathrm{SCN}^{-}$; luminosity $\left(\mathbf{L}^{*}\right.$, the degree of lightness from black to white), the degree of redness or greenness $\left(\mathrm{a}^{*}\right)$, and $\mathrm{b}^{*}$ values (collectively designated $\mathrm{L}^{*} \mathrm{a} \mathrm{b}^{*}$ values); and volatile compound analyses were performed immediately. Samples were frozen at $-80^{\circ} \mathrm{C}$ for norbixin, mineral, and proximate analysis at a later date (within $90 \mathrm{~d}$ ).

\section{Production of WPC80}

Treatments were selected based on current industrial practices, previous bleaching studies, and from the liquid whey trials $\left[\mathrm{LP}\left(20 \mathrm{mg}\right.\right.$ of $\left.\mathrm{H}_{2} \mathrm{O}_{2} / \mathrm{kg}\right)$ at $35 \mathrm{C}$, HP (250 mg of $\mathrm{H}_{2} \mathrm{O}_{2} / \mathrm{kg}$ ) at $50^{\circ} \mathrm{C}$, and control at $50^{\circ} \mathrm{C}$ ] for manufacture of WPC80. Hydrogen peroxide was a less effective bleaching agent at lower temperatures, so $50^{\circ} \mathrm{C}$ was selected for chemical bleaching (Listiyani et al., 2012). The optimum temperature for LP activity was $37^{\circ} \mathrm{C}$ and was selected for LP. The control was heated to $50^{\circ} \mathrm{C}$ to account for any effect of heat treatment (worstcase scenario). Colored, fat-separated cheese whey was freshly manufactured as described previously. The separated whey was transferred into a 102-L stainless vat (Fermenator; Blichmann Engineering LLC, Lafayette, IN) equipped with a coil heater $(1.3 \mathrm{~cm}$ o.d.; PAC Stainless Ltd., Seattle, WA). One of 3 treatments: LP $\left(35^{\circ} \mathrm{C}, 20 \mathrm{mg}\right.$ of $\mathrm{H}_{2} \mathrm{O}_{2} / \mathrm{kg}$ (35\% wt/vol; Nelson Jameson Inc.), $\mathrm{HP}\left(50^{\circ} \mathrm{C}, 250 \mathrm{mg}\right.$ of $\left.\mathrm{H}_{2} \mathrm{O}_{2} / \mathrm{kg}\right)$, or control $\left(50^{\circ} \mathrm{C}\right.$, no bleach added) was administered. The whey was allowed to bleach or was held at $50^{\circ} \mathrm{C}$ (control) for 1 $\mathrm{h}$ while recirculating using a peristaltic pump (model 77410-10; Millipore Inc., Billerica, MA). If any $\mathrm{H}_{2} \mathrm{O}_{2}$ remained after treatment, it was deactivated using 20 mg of catalase $/ \mathrm{kg}$ (FoodPro CAT, Danisco USA Inc.).
Wheys were then heated to $63^{\circ} \mathrm{C}$ for 30 min to pasteurize. Following pasteurization, the whey was cooled to the appropriate temperature (either 35 or $50^{\circ} \mathrm{C}$ ) before UF commenced. The UF system (model Pellicon 2; Millipore Inc.) was equipped with 5 polyethersulfone cartridge membrane filters (model P2B010V05, 10-kDa nominal separation cutoffs, $0.5 \mathrm{~m}^{2}$ surface area; Millipore Inc.). Each sample was run through a peristaltic pump (model 77410-10) and the UF assembly using silicone tubing (model 96440-73) that was connected to the vat. Pumps, pump heads, and tubing were all obtained from Cole-Palmer Instrument Co. (Vernon Hills, IL). This process continued until the retentate reached $80 \%$ protein (wt/vol) content confirmed by a Sprint rapid protein analyzer (CEM Corp., Matthews, NC). Retentates were then collected and spray dried (Model Lab 1; Anhydro Inc., Søborg, Denmark). The inlet temperature was $150^{\circ} \mathrm{C}$ and the outlet temperature was at $80^{\circ} \mathrm{C}$. The total spray-drying time was about 1 $\mathrm{h}$. The powder was collected and stored in Mylar bags at $-80^{\circ} \mathrm{C}$ following production. All treatments were manufactured from the same lot of milk and the experiment was carried out in triplicate.

\section{Composition Analysis}

Total solids of liquid whey and WPC80 were determined by air oven drying (AOAC, 2000; method number 990.20; 33.2.44). In powdered WPC80, fat was quantified by Soxhlet ether extraction (AOAC, 2000; method number 947.05). In liquid wheys, fat was quantified using the Pennsylvania modified Babcock method (AOAC, 2000; method number 989.04). Protein content was determined using the Kjeldahl method in powdered wheys (AOAC, 2000; method number 991.20; 33.2.11) or using the Sprint rapid protein analyzer (CEM Corp.) if the whey was liquid. Mineral analysis (phosphorus, calcium, magnesium, potassium, sulfur, sodium, and iron) was done by the North Carolina State University Analytical Services Laboratory (Raleigh, NC) using a standard dry ash method with inductively coupled plasma optical emission spectroscopy (Lloyd et al., 2009). All samples were measured in duplicate.

\section{Hunter $L^{*} a{ }^{*} b$ Values}

Whey protein concentrate $80 \%$ samples were measured in both powder form (10 g) and liquid form (10 $\mathrm{mL}$ of $10 \% \mathrm{wt} / \mathrm{vol}$ solution). Ten milliliters of the sample (rehydrated at $10 \% \mathrm{wt} / \mathrm{vol}$ solids, if necessary) was placed into the bottom of a $60 \times 15$-mm polystyrene Petri dish (Becton Dickinson and Co., Franklin Lakes, NJ). The color of the samples was measured using a Minolta Chroma meter (CR-410; Konica Minolta 
Sensing Americas Inc., Ramsey, NJ). Each sample was measured in duplicate and duplicate measurements were taken. Before measurements being taken, a factory-supplied calibration plate was used to calibrate the instrument. The Hunter Commission on Illumination (CIE) L*a*b* color scale was used. Reflectance values were taken with a white calibration plate as the background.

\section{Norbixin Extraction and Quantification}

Norbixin is the primary carotenoid in water-soluble annatto extracts and was extracted and measured to determine percent annatto destruction and bleaching efficacy (Kang et al., 2010). Norbixin was extracted using the methods described by Campbell et al. (2011) and quantified by HPLC. Briefly, $0.6 \mathrm{~g}$ of sample was weighed into a $50-\mathrm{mL}$ centrifuge tube (Nalge Nunc International Corp., Rochester, NY). To this, $6 \mathrm{~mL}$ of water was added and the sample was vortexed. Three milliliters of ethanol was added and the solution was then vortexed again. Three milliliters of chloroform (VWR International LLC) and $1 \mathrm{~mL}$ of glacial acetic acid (1\% wt/vol; JT Baker Chemical Co., Phillipsburg, NJ) were added to the previous solution. The sample was vortexed and centrifuged at $16,500 \times g$ for 10 min at $4^{\circ} \mathrm{C}$ (model RC5B; Thermo Scientific Inc., Waltham, MA). The bottom chloroform layer containing the norbixin was collected and the volume was measured. The extraction procedure and measurements were performed with premium full-spectrum F885 flat sheet filters covering all lights (Ergomart, Dallas, TX) to minimize norbixin isomerization and degradation (Mercadante, 2008).

To further filter and purify the extracted norbixin, solid-phase microextraction (SPME) was used. The column selected was the Strata- $\mathrm{NH}_{2}$ solid-phase extraction (SPE) column $(500 \mathrm{mg} / 3 \mathrm{~mL}$; Phenomenex Inc., Torrance, CA). To condition the column, $4 \mathrm{~mL}$ of $n$-hexane (VWR International LLC) was run through the column. An aliquot of the extract collected previously $(1 \mathrm{~mL})$ was transferred onto the conditioned SPE column. The column was rinsed with $2.5 \mathrm{~mL}$ of $n$-hexane:diethyl ether $(1: 1, \mathrm{vol} / \mathrm{vol})$ and $1 \mathrm{~mL}$ of acetone (VWR International LLC). The norbixin was eluted with $2 \mathrm{~mL}$ of methanol:glacial acetic acid (7:3, $\mathrm{vol} / \mathrm{vol}$ ). The final volume was measured and samples placed in vials for quantification by HPLC (Waters 1525 binary pump; Waters Corp., Milford, MA). Isocratic mobile phase $[70 \%$ acetonitrile $/ 30 \%$ water with $0.1 \%$ (wt/vol) formic acid (all from EMD Chemicals, VWR International LLC)] was used at a flow rate of $1 \mathrm{~mL} / \mathrm{min}$ pumped through a binary pump (Waters
1525, Waters Corp.). Fifteen microliters of the sample was injected (Waters 2707 autosampler) onto the column (Phenomenex Kinetex 2.6- $\mu \mathrm{m}$ particle size, 10-cm length, 4.6-mm i.d., 100A pore size; Phenomenex Inc.), which was heated to $40^{\circ} \mathrm{C}$. The injector temperature was set to $4^{\circ} \mathrm{C}$. The sample was sent through a photodiode array detector (Waters 2998). A standard curve was created by rehydrating norbixin powder (45\% (wt/ vol), Chr. Hansen, Milwaukee, WI) in 2.5\% (wt/vol) potassium hydroxide (BDH; VWR International LLC) and then diluting in methanol:glacial acetic acid (7:3, $\mathrm{vol} / \mathrm{vol}$ ). The maximum used for calculation was 460 $\mathrm{nm}$. Norbixin concentration was calculated by TS and correction for dilution during the extraction and SPE processes.

\section{LP Measurement}

Lactoperoxidase measurements and calculations were performed according to the International Dairy Federation method (Pruitt and Kamau, 1994). Two milliliters of ABTS stock solution [1 mM ABTS (Tokyo Chemical Industry Co. Ltd., Tokyo, Japan) in $0.1 \mathrm{~m} M$ phosphate buffer (pH 6.0; Electron Microscopy Sciences, Hatfield, $\mathrm{PA}$ )] was placed in a disposable plastic cuvette (VWR International LLC). To start the reaction, $0.10 \mathrm{~mL}$ of sample and $1.0 \mathrm{~mL}$ of $\mathrm{H}_{2} \mathrm{O}_{2}$ solution $(0.3 \mathrm{mM}$; Nelson Jameson Inc.) were added simultaneously and mixed thoroughly. The absorbance was monitored at $412 \mathrm{~nm}$ every $5 \mathrm{~s}$ until the reaction reached a plateau $(2-5$ min). Calculations were determined using the least squares regression of the absorbance data and Beer's law (Pruitt and Kamau, 1994). Samples for LP and thiocyanate measurement were taken from raw milk, pasteurized milk, whey (at drain), pasteurized whey, and pasteurized bleached whey.

\section{SCN Measurement}

Thiocyanate measurements were performed according to the International Dairy Federation method (IDF, 1988). Four milliliters of sample was mixed with 2.0 $\mathrm{mL}$ (wt/vol) of $20 \%$ TCA solution (BDH; VWR International LLC). The mixture was blended well and allowed to sit for at least $30 \mathrm{~min}$. The mixture was then centrifuged at $16,500 \times g$ for 10 min (model RC5B; Thermo Scientific Inc.). After centrifugation, $1.5 \mathrm{~mL}$ of the supernatant was mixed with $1.5 \mathrm{~mL}$ of ferric nitrate solution $\left[16 \mathrm{~g}\right.$ of $\mathrm{Fe}\left(\mathrm{NO}_{3}\right)_{3}$ (EMD Chemicals, VWR International LLC) dissolved in $50 \mathrm{~mL}$ of $2 \mathrm{M}$ nitric acid $\left(\mathrm{HNO}_{3} ; \mathrm{BDH}\right.$; VWR International LLC) and then diluted with deionized water to $100 \mathrm{~mL}$ ). The measurement was performed at $460 \mathrm{~nm}$ within $10 \mathrm{~min}$ 
of ferric nitrate solution addition. The concentration of $\mathrm{SCN}^{-}$(Sigma-Aldrich Co. LLC, Milwaukee, WI) was determined by the use of external standard curves.

\section{Descriptive Sensory Analysis}

Sensory analysis was conducted on rehydrated WPC80 ( $10 \% \mathrm{wt} / \mathrm{vol})$ using a trained descriptive sensory panel and an established dairy flavor language (Drake et al., 2003, 2009). Panelists $(\mathrm{n}=8)$ each had more than 150 $\mathrm{h}$ of previous experience with the sensory analysis of fluid and dried whey products using the Spectrum descriptive analysis method (Meilgaard et al., 2007). All sensory testing was conducted in accordance with the North Carolina State University Institutional Review Board for Human Subjects guidelines.

Reconstituted WPC80 (10\% solids wt/vol) was evaluated by placing $30 \mathrm{~mL}$ in 3-digit-coded $60-\mathrm{mL}$ lidded cups (Solo Cup Co., Urbana, IL). Preparations were conducted with overhead lights off to avoid exposure to light. The WPC80 were evaluated within $7 \mathrm{~d}$ of production. Samples were evaluated by each panelist in duplicate. Sensory data were collected on paper ballots or using Compusense 5 (release 4.8; Compusense Inc., Guelph, ON, Canada).

\section{GC-MS}

Volatile compounds in fluid whey and WPC80 powder were extracted by SPME using selective ion monitoring (SIM). Compounds were then separated and identified by GC-MS using a modified method of Liaw et al. (2010). Liquid samples were tested the day of manufacture and spray-dried powders were reconstituted at $10 \%$ solids (wt/vol) and evaluated within 7 d. All samples contained $10 \%$ (wt/vol) sodium chloride (Fisher Scientific, Pittsburgh, PA), and $10 \mu \mathrm{L}$ of internal standard solution (2-methyl-3-heptanone in methanol at $81 \mathrm{mg} / \mathrm{kg}$; Sigma-Aldrich Co. LLC) in 20$\mathrm{mL}$ autosampler vials with steel screw tops containing silicone septa faced in Teflon (MicroLiter Analytical Supplies Inc., Suwanee, GA). Samples were injected using a Combi PAL autosampler (CTC Analytics AG, Zwingen, Switzerland) attached to an Agilent 6890N gas chromatograph with 5973 inert mass selective detector (MSD; Agilent Technologies Inc., Santa Clara, $\mathrm{CA}$ ). Samples were maintained at $5^{\circ} \mathrm{C}$ before fiber exposure. Samples were equilibrated at $40^{\circ} \mathrm{C}$ for $25 \mathrm{~min}$ before 30-min fiber exposure of a 1-cm divinylbenzene/ Carboxen/polydimethylsiloxane (DVB/CAR/PDMS) fiber (Supelco Inc., Bellefonte, PA) at $31 \mathrm{~mm}$ with $4 \mathrm{~s}$ of pulsed agitation at $250 \mathrm{rpm}$. Fibers were injected for 5 min at a depth of $50 \mathrm{~mm}$.
The GC method used an initial temperature of $40^{\circ} \mathrm{C}$ for $3 \mathrm{~min}$ with a ramp rate of $10^{\circ} \mathrm{C} / \mathrm{min}$ to $250^{\circ} \mathrm{C}$ held for $5 \mathrm{~min}$. The SPME fibers were introduced into the split/splitless injector at $250^{\circ} \mathrm{C}$. A Zb-5ms column (Zb-5ms, 30-m length $\times 0.25-\mathrm{mm}$ i.d. $\times 0.25-\mu \mathrm{m}$ film thickness; Phenomenex Inc.) was used for all analyses at a constant flow rate of $1 \mathrm{~mL} / \mathrm{min}$. The purge time was set at $1 \mathrm{~min}$. The MS transfer line was maintained at $250^{\circ} \mathrm{C}$ with the quad at $150^{\circ} \mathrm{C}$ and source at $250^{\circ} \mathrm{C}$. Compounds were identified using the National Institute of Standards and Technology (NIST) 2005 library of spectra and comparison of spectra of authentic standards injected under identical conditions. Relative abundance for each compound was calculated using the calculated recovery of the internal standard concentration to determine relative concentrations of each compound. Retention indices were calculated using an alkane series (Sigma-Aldrich Co. LLC; van den Dool and Kratz, 1963).

\section{Statistical Analysis}

Data were analyzed by one-way ANOVA using a general linear model (PROC GLM) in SAS (version 9.2; SAS Institute Inc., Cary, NC). Replication was designated as a random effect. Principal component analysis was conducted and biplots were generated using XLSTAT (version 2010.5.02; Addinsoft, New York, NY).

\section{RESULTS}

\section{Liquid Whey}

The most effective bleaching with LP in unpasteurized, fat-separated liquid whey occurred with addition of $20 \mathrm{mg}$ of $\mathrm{H}_{2} \mathrm{O}_{2} / \mathrm{kg}$ (Figure 1) and this concentration was chosen for subsequent sets of experiments. Liquid whey was treated at either 35 or $50^{\circ} \mathrm{C}$ and received 1 of 3 treatments: $\mathrm{HP}\left(250 \mathrm{mg}\right.$ of $\left.\mathrm{H}_{2} \mathrm{O}_{2} / \mathrm{kg}\right)$, LP (20 mg of $\mathrm{H}_{2} \mathrm{O}_{2} / \mathrm{kg}$ ), or nothing (control). Samples did not differ in composition (solids $6.49 \pm 0.08$, protein $0.82 \pm$ 0.05 , and fat $0.03 \pm 0.01$ ). Samples bleached by the LP system showed the greatest bleaching efficacy $(>99 \%$ destruction of norbixin). Bleaching by LP did not vary with temperature for the bleaching time evaluated; however, bleaching by $\mathrm{H}_{2} \mathrm{O}_{2}$ was more effective at $50^{\circ} \mathrm{C}$ than at $35^{\circ} \mathrm{C}$ with 46.9 and $31.8 \%$ norbixin destruction, respectively $(P<0.05)$. Reflectance values were consistent with norbixin extraction values in that LP bleached better than $\mathrm{H}_{2} \mathrm{O}_{2}(P<0.05)$.

Both LP and $\mathrm{SCN}^{-}$were monitored from raw milk through whey pasteurization, which immediately fol- 


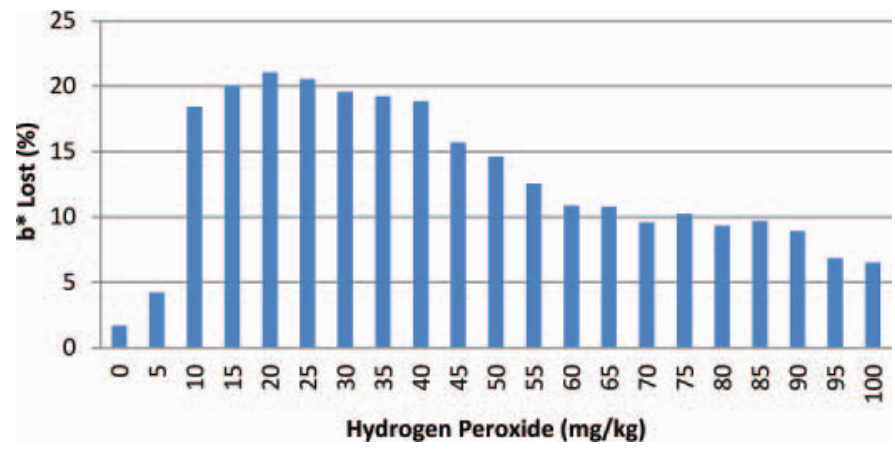

Figure 1. Bleaching efficacy of lactoperoxidase across various levels of hydrogen peroxide in unpasteurized, fat-separated fluid Cheddar whey at $35^{\circ} \mathrm{C}$ for $1 \mathrm{~h}$. $\mathrm{b}^{*}=$ degree of yellowness or blueness. Color version available in the online PDF.

lowed bleaching to ensure that neither of these changed over time or limited the system. The $\mathrm{SCN}^{-}$did not vary with bleaching type (LP, HP, or control), nor did it decrease over time $(P>0.05)$. Using an external standard curve for quantification, the $\mathrm{SCN}^{-}$level was $3.8 \pm 2.2 \mathrm{mg} / \mathrm{kg}$ in fluid whey, which is consistent with previously reported values of 3.2 to $4.6 \mathrm{mg} / \mathrm{kg}$ (Seifu et al., 2005). Lactoperoxidase was monitored throughout cheesemaking and was still active in samples receiving no bleach treatment after whey pasteurization (17.01 $\pm 1.4 \mathrm{U} / \mathrm{mL}$ ). Lactoperoxidase activity levels in unpasteurized fluid whey were not affected by fat separation $(P>0.05)$ but slightly increased following whey pasteurization, with values averaging $13.01 \pm 0.7 \mathrm{U} / \mathrm{mL}$ before pasteurization and $17.01 \pm 1.4 \mathrm{U} / \mathrm{mL}$ after pasteurization $(P<0.05)$. Previous studies have shown an LP activity decrease in milk after milk pasteurization (Seifu et al., 2005). We observed a consistent increase in LP activity in fluid whey after pasteurization. It is unknown why this increase occurred. A possible expla- nation may be due to small decreases in whey $\mathrm{pH}$ that occur between whey drain and vat pasteurization. The $\mathrm{pH}$ optimum for LP activity is between 5 and 6 . Whey is drained at $\mathrm{pH} 6.4$ and may decrease to 6.3 due to starter activity while being pumped to the vat pasteurizer and the temperature is increased to $63^{\circ} \mathrm{C}$. As the $\mathrm{pH}$ decreases closer to the optimal $\mathrm{pH}$, the activity of LP increases (Kussendrager and van Hooijdonk, 2000). In samples that received bleach treatment [either LP (20 mg of $\left.\mathrm{H}_{2} \mathrm{O}_{2} / \mathrm{kg}\right)$ or $\mathrm{HP}\left(250 \mathrm{mg}\right.$ of $\left.\left.\mathrm{H}_{2} \mathrm{O}_{2} / \mathrm{kg}\right)\right]$, no LP activity was detected after $30 \mathrm{~min}$. This suggests that bleaching by the LP system was a fast process, occurring within 30 min.

Volatile compound differences indicated that treatment had more of an effect than did temperature, with very few interactions. Octanal and 2,6-nonadienal were affected by temperature, whereas 2-pentylfuran, 1-octen-3-one, octanal, 2,4-nonadienal, 2,5-nonadienal, hexanal, and diacetyl were affected by treatment $(P<$ 0.05 ; Table 1). Only 2 interaction effects (temperature $\times$ treatment) were found: nonanal and heptanal $(P$ $<0.05$; Table 1). Methional, dimethyl trisulfide, and 1-hexen-3-one were not different between treatments or temperature $(P>0.05$; Table 1$)$. These volatile compounds have been previously documented to be associated with off flavors in both liquid and dried whey protein (Croissant et al., 2009; Whitson et al., 2010, 2011; Listiyani et al., 2011).

\section{WPC80}

Whey protein concentrate $80 \%$ did not differ in composition $(3.5 \pm 0.1 \%$ ash, $77.1 \pm 0.7 \%$ protein, and 4.7 $\pm 0.1 \%$ fat). Mineral composition was also not different (results not shown). Whey protein concentrate $80 \%$ from LP-bleached whey had lower norbixin content than did WPC80 from HP-bleached whey (99.4 vs.

Table 1. Relative abundance $(\mu \mathrm{g} / \mathrm{kg})$ of selected volatile compounds in unpasteurized, fat-separated fluid Cheddar whey after bleaching for $1 \mathrm{~h}^{1}$

\begin{tabular}{|c|c|c|c|c|c|c|}
\hline Compound & Control $35^{\circ} \mathrm{C}$ & Control $50^{\circ} \mathrm{C}$ & $\mathrm{HP} 35^{\circ} \mathrm{C}$ & $\mathrm{HP} 50^{\circ} \mathrm{C}$ & $\mathrm{LP} 35^{\circ} \mathrm{C}$ & $\mathrm{LP} 50^{\circ} \mathrm{C}$ \\
\hline Heptanal & $0.110^{\mathrm{c}}$ & $0.088^{\mathrm{c}}$ & $0.366^{\mathrm{c}}$ & $0.476^{\mathrm{bc}}$ & $2.20^{\mathrm{a}}$ & $1.21^{\mathrm{b}}$ \\
\hline 2,4-Nonadienal & $0.020^{\mathrm{b}}$ & $0.020^{\mathrm{b}}$ & $0.034^{\mathrm{b}}$ & $0.027^{\mathrm{b}}$ & $0.137^{\mathrm{a}}$ & $0.107^{\mathrm{a}}$ \\
\hline 2,6-Nonadienal & $0.043^{\mathrm{ab}}$ & $0.023^{\mathrm{b}}$ & $0.027^{\mathrm{b}}$ & $0.022^{\mathrm{b}}$ & $0.054^{\mathrm{a}}$ & $0.039^{\mathrm{ab}}$ \\
\hline Methional & $0.022^{\mathrm{a}}$ & $0.018^{\mathrm{a}}$ & $0.016^{\mathrm{a}}$ & $0.019^{\mathrm{a}}$ & $0.016^{\mathrm{a}}$ & $0.015^{\mathrm{a}}$ \\
\hline 1-Octen-3-one & $0.084^{\mathrm{b}}$ & $0.084^{\mathrm{b}}$ & $0.198^{\mathrm{b}}$ & $0.203^{\mathrm{b}}$ & $0.647^{\mathrm{a}}$ & $0.450^{\mathrm{a}}$ \\
\hline 1-Hexen-3-one & $0.015^{\mathrm{a}}$ & $0.164^{\mathrm{a}}$ & $0.034 \mathrm{a}$ & $0.033^{\mathrm{a}}$ & $0.095^{\mathrm{a}}$ & $0.088^{\mathrm{a}}$ \\
\hline Diacetyl & $0.184^{\mathrm{a}}$ & $0.169^{\mathrm{ab}}$ & $0.116 b^{c}$ & $0.094^{\mathrm{c}}$ & $0.156^{\mathrm{ab}}$ & $0.161^{\mathrm{ab}}$ \\
\hline
\end{tabular}

\footnotetext{
${ }^{\mathrm{a}-\mathrm{c}}$ Means in a row not sharing a common superscript are different $(P<0.05)$.

${ }^{1}$ Control samples received no bleach treatment, HP samples received $250 \mathrm{mg} / \mathrm{kg}$ addition of hydrogen peroxide, and LP samples received $20 \mathrm{mg} /$ $\mathrm{kg}$ addition of hydrogen peroxide, thus activating the lactoperoxidase (LP) system. Samples were bleached for $1 \mathrm{~h}$ at either 35 or $50^{\circ} \mathrm{C}$.
} 
Table 2. Hunter color values ${ }^{1}$ for dried and rehydrated whey protein concentrate $80 \%$ (10\% wt/vol)

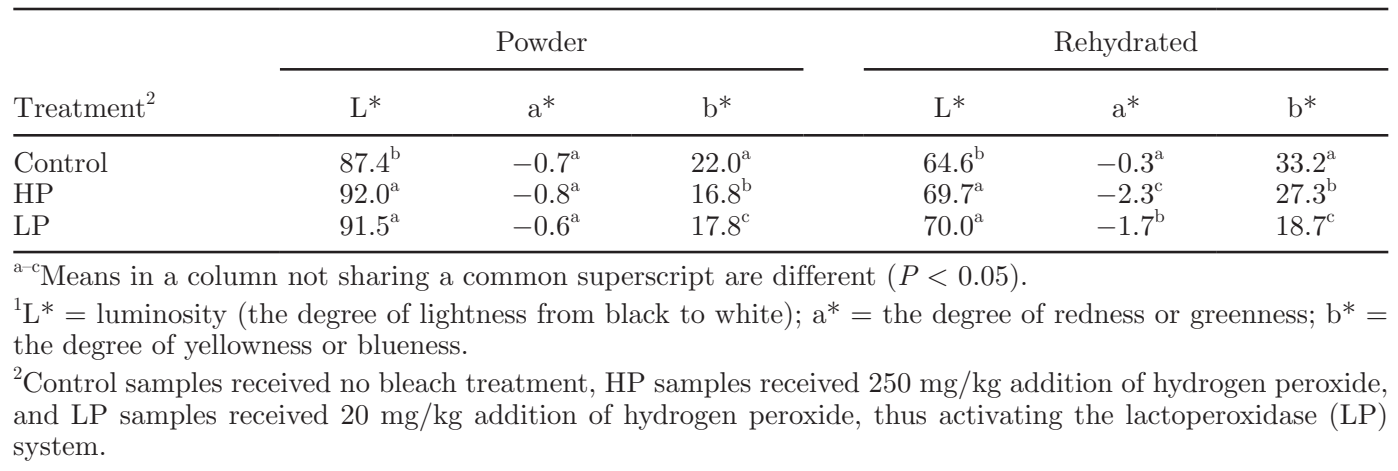

48.3\% destruction, respectively $(P<0.05)$, consistent with fluid whey trials. Reflectance values in rehydrated WPC80 (Table 2) were consistent with norbixin extraction results. Powdered WPC80 reflectance values were not in agreement with norbixin extraction results (Table 2). This is not unusual, as $\mathrm{b}^{*}$ measurements are an indirect measure of all yellow pigments, including naturally present carotenoids in milk and Maillard browning products, which can also contribute to color.

Whey protein concentrate $80 \%$ from bleached wheys (either HP or LP) were higher in aroma intensity and cardboard flavor and lower in sweet aromatic and cooked/milky flavors compared with the control WPC80 $(P<0.05$; Table 3$)$. Bleached whey proteins varied from each other in flavor in that LP-bleached WPC80 contained a very noticeable cabbage flavor, whereas WPC80 from HP-bleached whey displayed a fatty flavor $(P<0.05)$. Volatile results were consistent with sensory results. Whey protein concentrate $80 \%$ from either LP- or HP-bleached wheys were higher in hexanal, decanal, 1-hexen-3-one, 2,3-octadienone, benzacetaldehyde, heptanal, octanal, and 2-pentylfuran than the control unbleached WPC80 $(P<0.05$; Table $4)$. Whey protein concentrate $80 \%$ did not differ in pentanal, DMS, dimethyl trisulfide, sotolon, or diacetyl $(P>0.05$; Table 4$)$. Whey protein concentrate $80 \%$ from whey bleached with LP was significantly higher in heptanal, octanal, dimethyl disulfide, and 2-pentylfuran than those bleached with HP $(P<0.05$; Table 4$)$.

\section{DISCUSSION}

\section{Liquid Whey}

Lactoperoxidase is one of the most heat-stable enzymes, even retaining activity during normal pasteurization of milk (Seifu et al., 2005). Monitoring LP throughout cheesemaking (raw milk, pasteurized milk, whey, and pasteurized whey) showed minimal loss throughout processing, with LP still active in pasteurized whey. Lactoperoxidase constitutes about $1 \%$ of whey proteins in raw bovine milk, with reported activity ranging widely from 1.2 to $19.4 \mathrm{U} / \mathrm{mL}$; however, most recent literature in bovine milk points to the average being between 1.5 and $2.7 \mathrm{U} / \mathrm{mL}$ (Seifu et al., 2005). Variations of enzyme level in bovine milk can be attributed to the sexual cycle of the cow, season, feeding regimen, and breed (Kussendrager and van Hooijdonk, 2000). Thiocyanate levels were not different between samples or during processing $(P>0.05)$. Thiocyanate levels can vary depending on the feeding regimen of the animal (Reiter and Harnulv, 1984).

Table 3. Descriptive sensory profiles of whey protein concentrate $80 \%(\text { WPC } 80)^{1}$

\begin{tabular}{|c|c|c|c|c|c|c|c|}
\hline Treatment $^{2}$ & $\begin{array}{c}\text { Aroma } \\
\text { intensity }\end{array}$ & $\begin{array}{c}\text { Sweet } \\
\text { aromatic }\end{array}$ & Cardboard & Cabbage & Cooked/milky & Fatty & Astringency \\
\hline$\overline{\text { Control }}$ & $2.1^{\mathrm{b}}$ & $1.9^{\mathrm{a}}$ & $1.1^{\mathrm{b}}$ & $\mathrm{ND}^{3}$ & $2.2^{\mathrm{a}}$ & ND & $2.0^{\mathrm{a}}$ \\
\hline $\mathrm{HP}$ & $2.8^{\mathrm{a}}$ & $0.5^{\mathrm{b}}$ & $2.3^{\mathrm{a}}$ & ND & $1.5^{\mathrm{b}}$ & 1.2 & $1.8^{\mathrm{a}}$ \\
\hline
\end{tabular}

$\overline{\mathrm{a}, \mathrm{b}}$ Means in a column not sharing a common superscript are different $(P<0.05)$.

${ }^{1}$ Attribute intensities were scored on a 0 to 15 point universal intensity scale (Meilgaard et al., 2007). Most dried ingredient flavors fall between 0 and 4 (Croissant et al., 2009; Listiyani et al., 2011).

${ }^{2}$ Control samples received no bleach treatment, HP samples received $250 \mathrm{mg} / \mathrm{kg}$ addition of hydrogen peroxide, and LP samples received $20 \mathrm{mg} /$ $\mathrm{kg}$ addition of hydrogen peroxide, thus activating the lactoperoxidase (LP) system.

${ }^{3} \mathrm{ND}=$ not detected. 
Table 4. Relative abundance $(\mu \mathrm{g} / \mathrm{kg})$ of selected volatile compounds in whey protein concentrate $80 \%$ (WPC 80$)^{1}$

\begin{tabular}{lccc}
\hline Compound & Control & HP & LP \\
\hline Pentanal & $3.00^{\mathrm{a}}$ & $2.84^{\mathrm{a}}$ & $3.32^{\mathrm{a}}$ \\
Hexanal & $3.08^{\mathrm{b}}$ & $8.06^{\mathrm{a}}$ & $6.00^{\mathrm{a}}$ \\
Heptanal & $0.916^{\mathrm{c}}$ & $2.77^{\mathrm{b}}$ & $4.27^{\mathrm{a}}$ \\
Octanal & $0.481^{\mathrm{c}}$ & $1.89^{\mathrm{b}}$ & $3.63^{\mathrm{a}}$ \\
Nonanal & $2.87^{\mathrm{b}}$ & $4.00^{\mathrm{ab}}$ & $5.44^{\mathrm{a}}$ \\
Decanal & $0.070^{\mathrm{b}}$ & $0.124^{\mathrm{a}}$ & $0.131^{\mathrm{a}}$ \\
Dimethyl sulfide & $0.387^{\mathrm{a}}$ & $0.371^{\mathrm{a}}$ & $0.424^{\mathrm{a}}$ \\
Dimethyl disulfide & $0.131^{\mathrm{b}}$ & $0.313^{\mathrm{b}}$ & $3.12^{\mathrm{a}}$ \\
Dimethyl trisulfide & $0.483^{\mathrm{a}}$ & $0.519^{\mathrm{a}}$ & $0.515^{\mathrm{a}}$ \\
1-Hexen-3-one & $0.143^{\mathrm{b}}$ & $0.432^{\mathrm{a}}$ & $0.460^{\mathrm{a}}$ \\
2,3-Octadien-one & $2.00^{\mathrm{b}}$ & $5.09^{\mathrm{a}}$ & $5.49^{\mathrm{a}}$ \\
Benzacetaldehyde & $0.470^{\mathrm{b}}$ & $1.09^{\mathrm{a}}$ & $1.35^{\mathrm{a}}$ \\
Sotolon & $0.051^{\mathrm{a}}$ & $0.039^{\mathrm{a}}$ & $0.040^{\mathrm{a}}$ \\
2-Pentyl furan & $4.80^{\mathrm{c}}$ & $15.9^{\mathrm{b}}$ & $49.1^{\mathrm{a}}$ \\
Diacetyl & $0.048^{\mathrm{a}}$ & $0.027^{\mathrm{a}}$ & $0.040^{\mathrm{a}}$ \\
\hline
\end{tabular}

${ }^{\mathrm{a}-\mathrm{c}}$ Means in a row not sharing a common superscript are different $(P$ $<0.05)$.

${ }^{1}$ Control samples received no bleach treatment, HP samples received $250 \mathrm{mg} / \mathrm{kg}$ addition of hydrogen peroxide, and LP samples received 20 $\mathrm{mg} / \mathrm{kg}$ addition of hydrogen peroxide, thus activating the lactoperoxidase (LP) system.

The bleaching of whey by LP has not been well documented. Bottomley et al. (1989) found decolorization of whey to be between 50 and $85 \%$, depending on the amount of $\mathrm{SCN}^{-}$, HP, and LP. The level of bleaching achieved in this study was $>99 \%$, suggesting that the LP system was operating under optimal conditions. Previously, LP activity had been reported to be optimal between 11 and $15 \mathrm{mg} / \mathrm{kg}$ (Bottomley et al., 1989), which is in general agreement with the curve generated in this paper, as LP is known to vary slightly, which was previously discussed (Figure 1).

Previous research has not reported the volatile compounds produced specifically from the bleaching of whey using the LP system. Bleaching whey (by either $\mathrm{H}_{2} \mathrm{O}_{2}$ or benzoyl peroxide) increased lipid oxidation compounds (Croissant et al., 2009; Listiyani et al., 2011, 2012). Bleaching whey via the LP system yielded levels of hexanal, heptanal, ocatanal, nonanal, 2,4-nonadienal, and 2,6-nonadienal higher than unbleached wheys $(P$ $<0.05$ ) and concentrations similar to or higher than concentrations found in wheys with chemical bleaching (Table 1), suggesting that LP catalyzes lipid oxidation. The LP system generates $\mathrm{OSCN}^{-}$and ferrous iron, not only allowing for bleaching efficacy from $\mathrm{OSCN}^{-}$, but also from Fenton-type reactions that may further participate in bleaching efficacy and possible side reactions such as lipid oxidation. Lipid oxidation compounds are the source of fatty and cardboard off-flavors in dried whey proteins (Wright et al., 2009; Whitson et al., 2010). Further, lipid oxidation products formed in fluid whey contribute to these off-flavors in spray-dried whey proteins (Croissant et al., 2009; Listiyani et al., 2011; Whitson et al., 2011).

\section{WPC80}

In agreement with the first part of the study, WPC80 from whey bleached using the LP system contained $<1 \%$ residual norbixin (more norbixin destruction than those samples from whey bleached by HP). Reflectance values were consistent with norbixin destruction values in that LP bleached better than $\mathrm{H}_{2} \mathrm{O}_{2}$ alone $(P<0.05)$. Whey products devoid of any color are highly desirable (Kang et al., 2010).

Bleaching and bleach type have been previously shown to negatively affect the flavor of whey and spraydried whey proteins (Croissant et. al., 2009; Listiyani et al., 2011, 2012). Lipid oxidation products are the primary off-flavors found in dried whey proteins (Whitson et al., 2010, 2011) and contribute to undesirable off-flavors. Consistent with previous studies, bleached whey and WPC80 from bleached whey had higher concentrations of lipid oxidation products (such as aldehydes), cardboard flavor, and higher aroma intensities compared with unbleached whey and WPC80 from unbleached whey $(P<0.05)$. Source of bleaching also influenced flavor. Whey protein concentrate $80 \%$ from HP-bleached whey displayed a fatty flavor, whereas WPC80 from LP-bleached whey contained cabbage flavor. In addition, WPC80 bleached with LP were higher in heptanal, octanal, dimethyl disulfide, and 2 -pentylfuran than those bleached with $\mathrm{HP}(P<0.05)$. Bleaching with LP resulted in a whiter product (more norbixin destruction) than chemical bleach (HP), but also resulted in increased off-flavors compared with unbleached WPC80. The high amount of norbixin destruction (>99\%) using LP suggests that conditions might be optimized to decrease the amount of norbixin destruction while minimizing flavor contributions or to use LP in combination with another bleaching method.

\section{CONCLUSIONS}

The lactoperoxidase system has long been used in the dairy industry as an antimicrobial in raw milk but shows other potential applications, such as the bleaching of fluid whey. The LP system was activated by the addition of 10 to $40 \mathrm{mg}$ of $\mathrm{H}_{2} \mathrm{O}_{2} / \mathrm{kg}$, with an optimal concentration of $20 \mathrm{mg} / \mathrm{kg}$. Compared with HP bleaching, enzymatic bleaching was more effective in norbixin destruction, bleaching $>99 \%$, in both fluid whey and WPC80. Lipid oxidation products were higher in concentration in bleached wheys and WPC80 (either HP or LP) than in unbleached wheys or WPC80. Concur- 
rently, cardboard flavors were also increased in HP- or LP-bleached WPC80. These results support that sufficient LP bleaching may be obtained in less time, thereby optimizing bleaching efficacy while decreasing volatile loads and optimizing flavor. Future experiments should focus on the optimization of enzymatic bleaching in both fluid whey and liquid retentate.

\section{ACKNOWLEDGMENTS}

Funding was provided in part by the Dairy Research Institute [DRI; formerly Dairy Management Inc. (DMI), Rosemont, IL]. The advice and assistance of Brandon Nelson (Daisy Brand, Garland, TX) is gratefully acknowledged. The use of trade names does not imply endorsement or lack of endorsement by those not mentioned.

\section{REFERENCES}

AOAC (Association of Official Analytical Chemists). 2000. Official Methods of Analysis. 17th ed. AOAC, Gaithersburg, MD.

Bottomley, R. C., R. D. Colvin, and M. Van Blanton, inventors. 1989. Decolorising of whey and whey products derived from whey. Express Foods Group Limited (Middlesex, GB2), assignee. US Pat. No. $4,888,184$.

Campbell, R. E., R. E. Miracle, and M. A. Drake. 2011. The impact of starter culture and annatto on the flavor and functionality of whey protein concentrate. J. Dairy Sci. 94:1185-1193.

Croissant, A. E., E. J. Kang, R. E. Campbell, E. Bastian, and M. A. Drake. 2009. The effect of bleaching agent on the flavor of liquid whey and whey protein concentrate. J. Dairy Sci. 92:5917-5927.

de Wit, J. N., and A. C. M. van Hooijdonk. 1996. Structure, functions and applications of lactoperoxidase in natural antimicrobial systems. Neth. Milk Dairy J. 50:227-244.

Drake, M. A., Y. Karagul-Yuceer, K. R. Cadwallader, G. V. Civille, and P. S. Tong. 2003. Determination of the sensory attributes of dried milk powders and dairy ingredients. J. Sens. Stud. 18:199216.

Drake, M. A., R. E. Miracle, and J. M. Wright. 2009. Sensory properties of dairy proteins. Pages 429-448 in Milk Proteins: From Expression to Food. A. Thompson, M. Boland, and H. Singh ed. Elsevier, New York, NY.

IDF (International Dairy Federation). 1988. Code of practice for the preservation of raw milk by the lactoperoxidase system. Pages 5-8 in Bulletin of the International Dairy Federation No. 234. International Dairy Federation, Brussels, Belgium.
Kang, E. J., R. E. Campbell, E. Bastian, and M. A. Drake. 2010 Invited review: Annatto and bleaching in dairy foods. J. Dairy Sci. 93:3891-3901.

Kussendrager, K. D., and A. C. M. van Hooijdonk. 2000. Lactoperoxidase: Physico-chemical properties, occurrence, mechanism of action, and applications. Br. J. Nutr. 84:S19-S25.

Liaw, I. W., H. Eshpari, P. S. Tong, and M. A. Drake. 2010. The impact of antioxidant addition on flavor of Cheddar and Mozzarella whey and Cheddar whey protein concentrate. J. Food Sci. 75:C559-C569.

Listiyani, M. A. D., R. E. Campbell, R. E. Miracle, D. M. Barbano, P. D. Gerard, and M. A. Drake. 2012. Impact of fat separation, temperature, and bleaching agent on bleaching of liquid Cheddar whey. J. Dairy Sci. 95:36-49.

Listiyani, M. A. D., R. E. Campbell, R. E. Miracle, L. O. Dean, and M. A. Drake. 2011. Influence of bleaching on flavor of $34 \%$ whey protein concentrate and residual benzoic acid concentration in dried whey proteins. J. Dairy Sci. 94:4347-4359.

Lloyd, M. A., S. J. Hess, and M. A. Drake. 2009. Effect of nitrogen flushing and storage temperature on flavor and shelf-life of whole milk powder. J. Dairy Sci. 92:2409-2422.

Meilgaard, M. C., G. V. Civille, and B. T. Carr. 2007. The Spectrum descriptive analysis method. Pages 189-253 in Sensory Evaluation Techniques. CRC Press, Boca Raton, FL.

Mercadante, A. Z. 2008. Analysis of carotenoids. Pages 447-478 in Food Colorants: Chemical and Functional Properties. C. Socaciu, ed. CRC Press, Boca Raton, FL.

Pruitt, K. M., and D. N. Kamau. 1994. Quantitative analysis of bovine lactoperoxidase system components and the effects of the activated system on bacterial growth and survival. Pages 73-87 in Indigenous Antimicrobial Agents of Milk-Recent Developments. International Dairy Federation, Brussels, Belgium.

Reiter, B., and B. G. Harnulv. 1982. The preservation of refrigerated and uncooled milk by its natural lactoperoxidase system. Dairy Ind. Int. 47:13-19.

Reiter, B., and B. G. Harnulv. 1984. Lactoperoxidase antibacterial system: Natural occurrence, biological functions, and practical applications. J. Food Prot. 47:724-732.

Seifu, E., E. M. Buys, and E. F. Donkin. 2005. Significance of the lactoperoxidase system in the dairy industry and its potential applications: A review. Trends Food Sci. Technol. 16:137-154.

van den Dool, H., and P. D. Kratz. 1963. A generalization of retention index system including linear temperature programmed gas-liquid partition chromatography. J. Chromatogr. A 11:463-467.

Whitson, M. E., R. E. Miracle, E. Bastian, and M. A. Drake. 2011. Effect of liquid retentate storage on flavor of spray-dried whey protein concentrates and isolate. J. Dairy Sci. 94:3747-3760.

Whitson, M. E., R. E. Miracle, and M. A. Drake. 2010. Sensory characterization of chemical components responsible for cardboard flavor in whey protein. J. Sens. Stud. 25:616-636.

Wright, B. J., S. E. Zevchak, J. M. Wright, and M. A. Drake. 2009. The impact of agglomeration and storage on flavor and flavor stability of whey protein concentrate $80 \%$ and whey protein isolate. J. Food Sci. 74:S17-S29. 